\title{
REVIEWS.
}

\section{THE EARLY TREATMENT OF WAR WOUNDS.}

By William Anderson, O.B.E. (Mil.), M.B., Ch.B., F.R.C.S. Oxford University Press. I94I. Price 5 s.

This little book will be useful to doctors taking up work with the Forces and who have had no previous experience or training. It is obviously meant as a guide to medical practitioners who will have to work in a strange environment. Now that the war is nearly two years old, it seems a little out of date, as it is written from experience in the last war, where conditions were static, whereas now conditions would appear to be much more fluid than had previously been thought possible.

Mr. Anderson's clinical remarks are admirable, and especially would we comment on the two chapters on penetrating wounds of the abdomen and of the thorax, in which he has condensed in very few words admirable lessons, obviously based on experience. But as this type of injury now is treated so much by specialists it is doubtful if these serve much purpose in a book of this character. They are not sufficiently elaborated or discussed for the specialists ; they are out of place for the junior medical officer.

Not all surgeons would agree with Mr. Anderson's treatment of injury to the knee joint, especially in the matter of lateral incisions; but this is, of course, a matter of opinion. We are also surprised to note his advocacy of the internal angular splint. One had imagined that this splint had already been discarded into the limbo of oblivion, where it should belong. We are surprised, too, that amputation through the knee joint is recommended in a bad case of gas gangrene with the posterior tibial artery divided. This will only involve another amputation, and the additional shock of amputating at the site of election in the thigh is very little more, and will save the patient from another amputation later on. We do most heartily agree with $\mathrm{Mr}$. Anderson, however, when he says that of the many errors made in the diagnosis of abdominal injuries, he doubts if many can be attributed to the giving of morphia.

We can recommend this book, which is very short, very concise and a useful guide to those starting on a military career.

\section{TECHNIQUE OF GASTRIC OPERATIONS.}

By Rodney Maingot, F.R.C.S. Oxford University Press. I94I. Price I5s.

This is a record of the professional experience of the author with a full and comprehensive description of the methods employed by him in the performance of certain gastric operations.

In the "Technique of Gastric Operations," the meticulous critic may point out certain omissions of well-known gastric disorders for which operation has been recommended and performed. But as this is a personal record, the work is not to be regarded as a text-book, and its value is by no means diminished because it does not contain a full record of other people's methods.
Not every surgeon will agree with all the views of Mr. Maingot. For example, his preference for silk, especially in closing the abdominal wall, will probably not be accepted by many. As a description of his own technique, however, the book is not only interesting but full of information, and is definitely of value to surgeons. The descriptions (especially of gastrectomy) are lucid, well expressed, and perfectly clear ; they are well illustrated in a somewhat diagrammatic manner. The book is written in simple language, so that there can be no doubt as to the author's meaning. In fact, it is definitely dogmatic, which is perhaps a good thing in a book of this kind.

There are one or two statements which we think are perhaps a little unjustified; for instance, in dealing with perforated gastric ulcer, the author says that the operation of simple suture " does not necessitate any special experience or skill in abdominal surgery." We think that this is a dangerous statement, and though we agree with Mr. Maingot that this is the operation of choice and that more complicated operations, including gastrectomy, are inadmissible, simple suture may involve great difficulties and require skill and experience for their satisfactory closure. Nor are we entirely in agreement with the author in his condemnation of clamps. We agree that a higher gastrectomy can be performed without the use of clamps, but in certain other cases, especially in gastroenterostomy and other anastomoses, clamps have always had, and probably will continue to have, a very definite place in the technique.

We can compliment the author on this book, which is well produced, easy to read, and is a valuable addition to any surgeon's library.

\section{A TEXTBOOK OF HISTOLOGY FOR MEDICAL STUDENTS.}

By Evelyn E. Hewer, D.Sc. Second Edition. William Heinemann (Medical Books), Ltd., London. 1941. Price 17s. 6d.

After àn experience of teaching medical students extending over a period of twenty-one years the author published the first edition of her textbook written primarily for them. A notable feature of the book is the photomicrographic illustrations of the text, showing histological appearances under low magnification. The more minute structure of tissues is shown by diagrammatic drawings of appearances under higher magnifications. In the appendix descriptions are given of histological technique. In this second edition certain important additions have been made. Recent work on the development of blood corpuscles is incorporated, together with details of arterio-venous connections. The physiolocal basis of the changes occurring during the menstrual cycle receives attention.

This is a first-class book on histology, admirably adapted for medical students to whom it is recommended with every confidence. After her long experience in teaching, Dr. Hewer is conversant with the students' needs and has provided a textbook to meet those needs. 